\title{
Nocardioides panacisoli sp. nov., isolated from the soil of a ginseng field
}

Correspondence
Song-Gun Kim
sgkim@kribb.re.kr

\author{
Chun Hwi Cho, ${ }^{1}$ Jung-Sook Lee, ${ }^{2}$ Dong-Shan $\mathrm{An}^{2}{ }^{2}$ Tae Woong Whon ${ }^{2}$ \\ and Song-Gun Kim ${ }^{2}$
}
${ }^{1}$ Department of Bio-Environmental Chemistry, Chungnam National University, Daejeon 305-764, Republic of Korea
${ }^{2}$ Korean Collection for Type Cultures, Biological Resource Center, Korea Research Institute of Bioscience and Biotechnology, 52 Eoeun-dong, Yuseong-gu, Daejeon 305-806, Republic of Korea

A Gram-positive, rod-shaped, non-spore-forming bacterium (Gsoil $346^{\top}$ ) was isolated from the soil of a ginseng field in South Korea and was characterized in order to determine its taxonomic position. On the basis of $16 \mathrm{~S}$ rRNA gene sequences, strain Gsoil $346^{\top}$ was shown to belong to the genus Nocardioides in the family Nocardioidaceae, with the most closely related species being Nocardioides aquiterrae GW-9 ${ }^{\top}$ (96.6\% 16S rRNA gene sequence similarity); however, the strain clustered in a distinct branch of the phylogenetic tree with Nocardioides kongjuensis A2-4 $4^{\top}$ (96.2\%), Nocardioides aromaticivorans $\mathrm{H}-1^{\top}$ (96.1\%), Nocardioides nitrophenolicus NSP41 ${ }^{\top}$ (96.1\%) and Nocardioides simplex ATCC $15799^{\top}(95.9 \%)$. Strain Gsoil $346^{\top}$ was characterized chemotaxonomically and found to have LL-2,6-diaminopimelic acid in the cell-wall peptidoglycan, phosphatidylinositol and phosphatidylglycerol as the major polar lipids, $\mathrm{MK}-8\left(\mathrm{H}_{4}\right)$ as the predominant menaquinone and iso- $\mathrm{C}_{16: 0}, \mathrm{C}_{18: 1} \omega 9 \mathrm{c}$ and $\mathrm{C}_{17: 1} \omega 8 \mathrm{c}$ as the major fatty acids. The $\mathrm{G}+\mathrm{C}$ content of the genomic DNA of the novel strain was $73.0 \mathrm{~mol} \%$. These chemotaxonomic properties supported the placement of strain Gsoil $346^{\top}$ in the genus Nocardioides. The results of physiological and biochemical tests, along with the phylogenetic analysis, allowed strain Gsoil $346^{\top}$ to be differentiated genotypically and phenotypically from recognized species of the genus Nocardioides. Therefore, strain Gsoil $346^{\top}$ represents a novel species, for which the name Nocardioides panacisoli sp. nov. is proposed, with Gsoil $346^{\top}$ $\left(=\right.$ KCTC $19470^{\top}=$ DSM $\left.21348^{\top}\right)$ as the type strain.
The genus Nocardioides was proposed by Prauser (1976) and, at the time of writing, comprised 37 species with validly published names. The genus has been expanding rapidly in recent years: seven novel species were reported in 2007 and nine novel species were reported in 2008, including Nocardioides agariphilus (Dastager et al., 2008), Nocardioides daphniae (Tóth et al., 2008) and Nocardioides hwasunensis (Lee et al., 2008). The species in this genus have been isolated from diverse habitats. For example, Nocardioides aestuarii (Yi \& Chun, 2004) and Nocardioides salarius (Kim et al., 2008) were isolated from marine sources, Nocardioides panacihumi (An et al., 2007) and Nocardioides kongjuensis (Yoon et al., 2006) were isolated from terrestrial sources and Nocardioides fonticola (Chou

The GenBank/EMBL/DDBJ accession number for the $16 \mathrm{~S}$ rRNA gene sequence of strain Gsoil $346^{\top}$ is FJ666101.

A supplementary figure showing the polar lipid profile of strain Gsoil $346^{\top}$ and a table detailing the cellular fatty acid profiles of strain Gsoil $346^{\top}$ and related type strains are available as supplementary material with the online version of this paper. et al., 2008) was isolated from a freshwater spring. Importantly, some species in the genus have been isolated from environments that were polluted with organic compounds, e.g. Nocardioides aromaticivorans (Kubota et al., 2005) and Nocardioides oleivorans (Schippers et al., 2005).

During a study of the culturable aerobic bacterial community of the soil from a ginseng field in Pocheon province, South Korea, a large number of novel bacterial strains were isolated (Im et al., 2005). One of these isolates, strain Gsoil $346^{\mathrm{T}}$, was identified as a member of the genus Nocardioides in the family Nocardioidaceae. To determine the precise taxonomic designation of this strain, we conducted a phylogenetic analysis using 16S rRNA gene sequences and chemotaxonomic and phenotypic tests were used to determine important characteristics.

Strain Gsoil $346^{\mathrm{T}}$ was isolated from the soil of a ginseng field in Pocheon province in South Korea $\left(37^{\circ} 58^{\prime} \mathrm{N}\right.$ $\left.127^{\circ} 15^{\prime} \mathrm{E}\right)$. Soil was well suspended with $50 \mathrm{mM}$ pot- 
assium phosphate buffer ( $\mathrm{pH} 7.0)$ and serial dilutions were spread on modified R2A agar (per litre: $0.25 \mathrm{~g}$ tryptone, $0.25 \mathrm{~g}$ peptone, $0.25 \mathrm{~g}$ yeast extract, $0.125 \mathrm{~g}$ malt extract, $0.125 \mathrm{~g}$ beef extract, $0.25 \mathrm{~g}$ Casamino acids, $0.25 \mathrm{~g}$ soytone, $0.5 \mathrm{~g}$ glucose, $0.3 \mathrm{~g}$ soluble starch, $0.2 \mathrm{~g}$ xylan, $0.3 \mathrm{~g}$ sodium pyruvate, $0.3 \mathrm{~g} \mathrm{~K}_{2} \mathrm{HPO}_{4}, 0.05 \mathrm{~g} \mathrm{MgSO}_{4}, 0.05 \mathrm{~g}$ $\mathrm{CaCl}_{2}, 15 \mathrm{~g}$ agar, $\mathrm{pH}$ 7.2). The plates were incubated at $30{ }^{\circ} \mathrm{C}$ for 1 month under aerobic conditions. Single colonies were subcultured on modified R2A agar and incubated at $30{ }^{\circ} \mathrm{C}$ for 1 week. The identities of the purified colonies were tentatively determined by sequencing a portion of the 16S rRNA gene (Im et al., 2005). Strain Gsoil $346^{\mathrm{T}}$ was one of the predominant isolates. The strain was subsequently routinely cultured on R2A agar (Difco; Reasoner \& Geldreich, 1985) at $30{ }^{\circ} \mathrm{C}$ and preserved as a glycerol suspension $(20 \%, \mathrm{v} / \mathrm{v})$ at $-70{ }^{\circ} \mathrm{C}$.

The Gram-reaction was determined by the non-staining method as described by Buck (1982). Morphology of cells after growth at $30{ }^{\circ} \mathrm{C}$ for 4 days on R2A agar was observed under a phase-contrast microscope (Optiphot-2, Nikon) at $\times 1000$ magnification. Catalase activity was determined by bubble production in $3 \%(\mathrm{v} / \mathrm{v}) \mathrm{H}_{2} \mathrm{O}_{2}$ and oxidase activity was determined using $1 \%(\mathrm{w} / \mathrm{v})$ tetramethyl $p$-phenylenediamine. For single-carbon-source assimilation studies, a defined liquid medium containing basal salts was used (per litre: $1.8 \mathrm{~g} \mathrm{~K}_{2} \mathrm{HPO}_{4}, 1.08 \mathrm{~g} \mathrm{KH}_{2} \mathrm{PO}_{4}, 0.5 \mathrm{~g} \mathrm{NaNO}_{3}, 0.5 \mathrm{~g}$ $\mathrm{NH}_{4} \mathrm{Cl}, 0.1 \mathrm{~g} \mathrm{KCl}, 0.1 \mathrm{~g} \mathrm{MgSO}_{4}, 0.05 \mathrm{~g} \mathrm{CaCl}_{2}$ ), with the addition of vitamin solution (Widdel \& Bak, 1992), trace element solution SL-10 (Widdel et al., 1983) and selenite/ tungstate solution (Tschech \& Pfennig, 1984) and the $\mathrm{pH}$ adjusted to $\mathrm{pH} 6.8$. This liquid medium was poured into 96-well plates $(0.25 \mathrm{ml}$ per well $)$ and filter-sterilized carbon sources $(0.1 \%$ final concentration, w/v) were added into each well. The plates were incubated at $30{ }^{\circ} \mathrm{C}$ and growth was examined visually for up to 7 days. Negative control wells did not contain any of the carbon sources and positive control wells contained R2A broth. Some physiological characteristics were determined with API 20E and API ZYM galleries (bioMérieux) according to the manufacturer's instructions. Degradation of DNA [using DNase agar (Scharlau), supplemented with $1 \mathrm{M} \mathrm{HCl}$, degradation of casein, chitin and starch (Atlas, 1993) and degradation of xylan and cellulose (Ten et al., 2004) were also investigated; reactions were read after 5 days. Growth at different temperatures $\left(4,10,18,30,37,42\right.$ and $\left.45{ }^{\circ} \mathrm{C}\right)$ and various $\mathrm{pH}$ values $(\mathrm{pH} 5.0-10.0$ at intervals of $0.5 \mathrm{pH}$ units) was assessed with R2A agar after 5 days of incubation. The following biological buffers $(50 \mathrm{mM})$ were used to adjust the $\mathrm{pH}$ of the media: $\mathrm{Na}_{2} \mathrm{HPO}_{4} / \mathrm{NaH}_{2} \mathrm{PO}_{4}$ for $\mathrm{pH}$ 5.0-8.0 and $\mathrm{Na}_{2} \mathrm{CO}_{3} / \mathrm{NaHCO}_{3}$ for $\mathrm{pH} 8.5-10.0$ (Bates \& Bower, 1956; Gomori, 1955). Salt tolerance was tested on R2A agar supplemented with $1-10 \%(\mathrm{w} / \mathrm{v}) \mathrm{NaCl}$ after 5 days incubation at $30{ }^{\circ} \mathrm{C}$.

Extraction of genomic DNA was performed using a commercial genomic DNA extraction kit (Core Biosystem). PCR-mediated amplification of the $16 \mathrm{~S}$ rRNA gene and sequencing of the purified PCR product were carried out using six primers, according to Kim et al. (2005), to almost cover the complete sequence of the $16 \mathrm{~S}$ rRNA gene. The sequences were compiled using SeqMan software (DNASTAR) and resulted in a partial sequence of $1449 \mathrm{bp}$. The 16S rRNA gene sequences of related taxa were obtained from the GenBank database. Sequence similarity values were calculated by the EzTaxon server (Chun et al., 2007). Multiple alignments were performed using CLUSTAL_X (Thompson et al., 1997). Gaps were edited in the BioEdit program (Hall, 1999). The evolutionary distances were calculated using the Kimura two-parameter model (Kimura, 1983) and pairwise deletion. The phylogenetic tree was constructed with the neighbour-joining (Saitou \& Nei, 1987) and maximum-parsimony methods (Fitch, 1971) using MEGA4 software (Kumar et al., 2007). The software package PHYLIP version 3.67 (Felsenstein, 2004) was used for the phylogenetic analysis based on the maximum-likelihood algorithm. The resultant tree topologies were evaluated using bootstrap analysis (Felsenstein, 1985) based on 1000 replications for the neighbour-joining and maximum-parsimony methods and on 100 resampled datasets for the maximum-likelihood algorithm.

To measure the $\mathrm{G}+\mathrm{C}$ content of the chromosomal DNA, genomic DNA was extracted from strain Gsoil $346^{\mathrm{T}}$ and purified as described by Moore \& Dowhan (1995), enzymically degraded into nucleosides and analysed as described by Mesbah et al. (1989) using reversed-phase HPLC. Isoprenoid quinones were extracted with chloroform/methanol $(2: 1, \mathrm{v} / \mathrm{v})$, evaporated under a vacuum and re-extracted in $n$-hexane/water $(1: 1, \mathrm{v} / \mathrm{v})$, purified from the $n$-hexane fraction using Sep-Pak (Waters) and analysed by HPLC, as described by Hiraishi et al. (1996). Cellular fatty acids were analysed from bacterial cells grown on trypticase soy agar (TSA; Difco) for 2 days at $30{ }^{\circ} \mathrm{C}$. The cellular fatty acids were converted to the corresponding methyl esters, extracted according to the protocol of the Sherlock Microbial Identification System (MIDI), analysed by gas chromatography (Hewlett Packard 6890) and identified by the Microbial Identification software package (Sasser, 1990). The presence of diaminopimelic acid isomers in the cell-wall peptidoglycan was determined by TLC after hydrolysis with $6 \mathrm{M} \mathrm{HCl}$ at $100{ }^{\circ} \mathrm{C}$ for $18 \mathrm{~h}$ as described by Komagata \& Suzuki (1987). Polar lipids were extracted, separated and identified by two-dimensional TLC and staining with molybdenum blue spray (M1942; Sigma), as described by Minnikin et al. (1977).

Strain Gsoil $346^{\mathrm{T}}$ was Gram-positive, strictly aerobic, nonendospore-forming, non-motile and short rod-shaped. Colonies grown on R2A agar plates at $30{ }^{\circ} \mathrm{C}$ for 4 days were smooth, circular, light yellowish white in colour, convex and $1-3 \mathrm{~mm}$ in diameter. The temperature range for growth of strain Gsoil $346^{\mathrm{T}}$ on R2A agar was $10-42{ }^{\circ} \mathrm{C}$ (optimum $18-37{ }^{\circ} \mathrm{C}$ ) and there was no growth at $4{ }^{\circ} \mathrm{C}$ or $45^{\circ} \mathrm{C}$. The physiological characteristics of strain Gsoil $346^{\mathrm{T}}$ are summarized in the species description and a comparison of selective characteristics with those of related type strains is given in Table 1. 
Table 1. Physiological characteristics of strain Gsoil $346^{\top}$ and closely related type strains of species in the genus Nocardioides

Strains: 1, Nocardioides panacisoli sp. nov. Gsoil $346^{\mathrm{T}}$ (data from this study); 2, N. aromaticivorans DSM 15131 ${ }^{\mathrm{T}}$ (Kubota et al., 2005); 3, N. nitrophenolicus JCM 10703 ${ }^{\mathrm{T}}$ (Yoon et al., 1999); 4, N. simplex JCM 1363 ${ }^{\mathrm{T}}$ (Suzuki \& Komagata, 1983; Yoon et al., 1999; Kubota et al., 2005); 5, N. kongjuensis KCTC $19054^{\mathrm{T}}$ (Yoon et al., 2006). All strains were positive for catalase and alkaline phosphatase. All strains were negative for esterase lipase (C8), $\alpha$ - and $\beta$-galactosidases and $\alpha$-mannosidase. + , Positive; $w$, weakly positive; - , negative; ND, no data available.

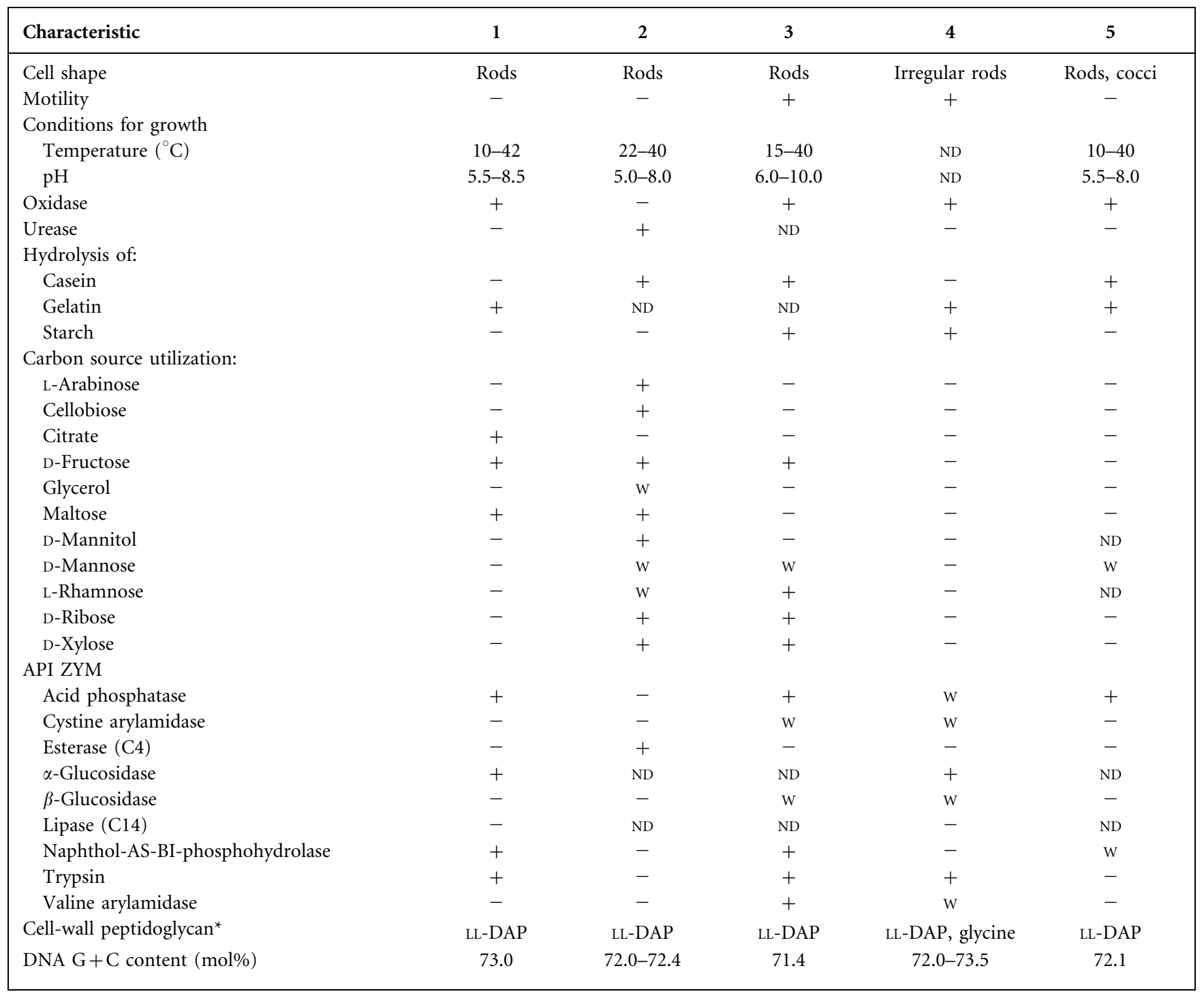

${ }^{\star}$ DAP, diaminopimelic acid.

The 16S rRNA gene sequence of strain Gsoil $346^{\mathrm{T}}$ determined in this study was a continuous stretch of $1449 \mathrm{bp}$. The closest relative of strain Gsoil $346^{\mathrm{T}}$ was Nocardioides aquiterrae GW- $9^{\mathrm{T}}(96.6 \%$ 16S rRNA gene sequence similarity), but strain Gsoil $346^{\mathrm{T}}$ formed a monophyletic clade with $N$. kongjuensis $\mathrm{A} 2-4^{\mathrm{T}}, N$. aromaticivorans $\mathrm{H}-1^{\mathrm{T}}$, Nocardioides nitrophenolicus $\mathrm{NSP}^{\mathrm{T}} \mathrm{1}^{\mathrm{T}}$ and Nocardioides simplex ATCC $15799^{\mathrm{T}}$ in a neighbour-joining phylogenetic tree, which was supported by a robust bootstrap value of $89 \%$. This tree topology was also supported by the maximum-likelihood algorithm (Fig. 1).
Strain Gsoil $346^{\mathrm{T}}$ contained $\mathrm{MK}-8\left(\mathrm{H}_{4}\right)$ as the major menaquinone and LL-2,6-diaminopimelic acid as the diagnostic cell-wall diamino acid. The DNA G + C content was $73.0 \mathrm{~mol} \%$. All of these chemotaxonomic characteristics supported the affiliation of strain Gsoil $346^{\mathrm{T}}$ to the genus Nocardioides. The major fatty acid profile of strain Gsoil $346^{\mathrm{T}}$ contained mainly iso- $\mathrm{C}_{16: 0}(28.0 \%), \mathrm{C}_{18: 1} \omega 9 c$ $(10.7 \%)$ and $C_{17: 1} \omega 8 c(9.0 \%)$, which is similar to those of other Nocardioides species, but the minor fatty acid profile was significantly different from those of the most closely related species of the genus Nocardioides: the saturated fatty 


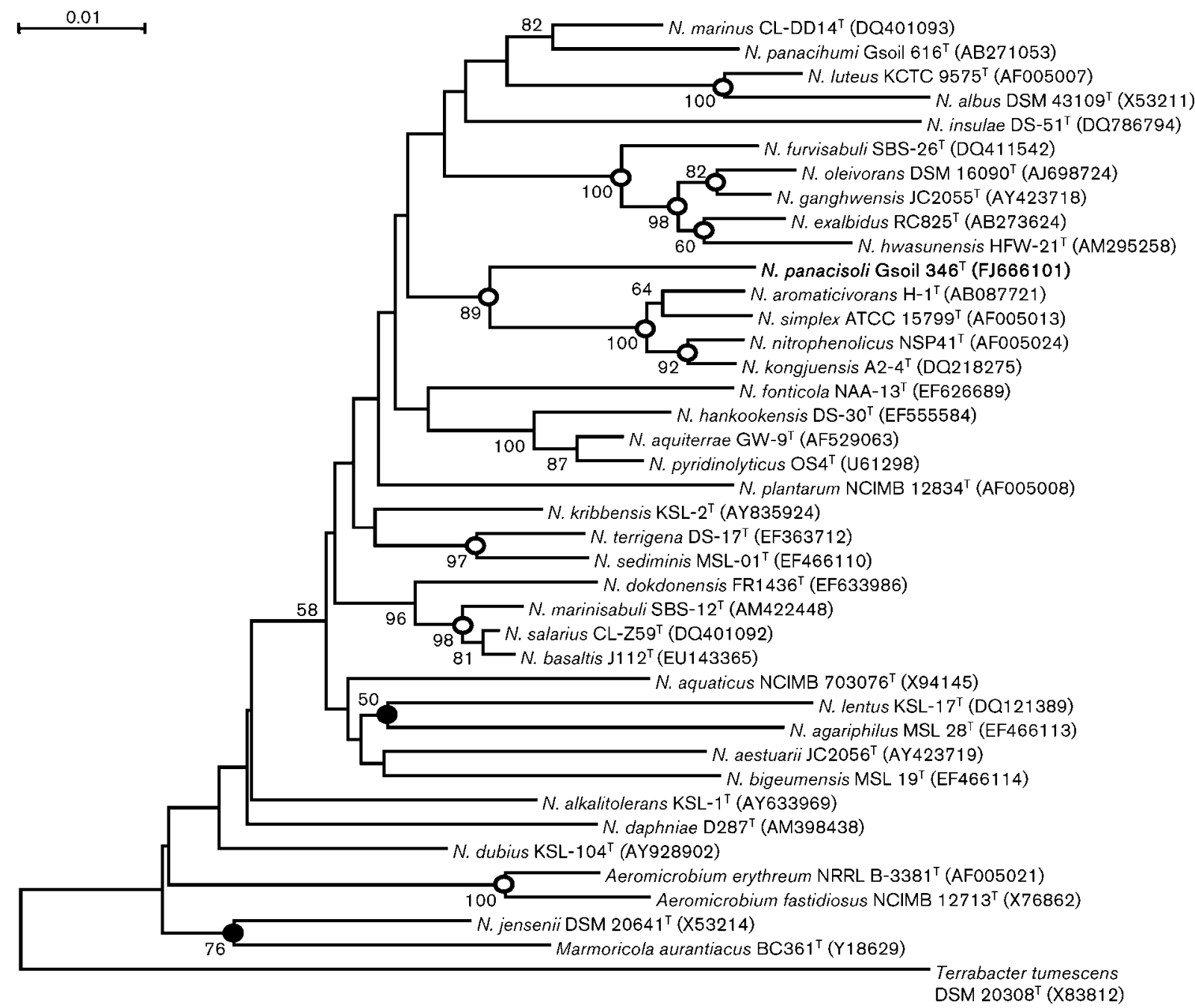

Fig. 1. Neighbour-joining phylogenetic tree based on a comparative analysis of $16 \mathrm{~S}$ rRNA gene sequences, showing the relationships between strain Gsoil $346^{\top}$ and type strains of species in the genus Nocardioides. Bootstrap values ( $>50 \%$ ) based on 1000 replications are shown at branch nodes. Solid circles indicate that the corresponding branches were also recovered in maximum-parsimony and maximum-likelihood trees. Open circles indicate that the corresponding nodes were also recovered in the maximum-likelihood tree. Bar, 0.01 substitutions per nucleotide position.

acid $\mathrm{C}_{15: 0}$ was unique to strain Gsoil $346^{\mathrm{T}}, \mathrm{C}_{16: 0} 2-\mathrm{OH}$ was found only in strain Gsoil $346^{\mathrm{T}}$ and N. kongjuensis KCTC $19054^{\mathrm{T}}$, and $\mathrm{C}_{16: 0}$ 10-methyl, found in N. simplex JCM $1363^{\mathrm{T}}$ and $N$. kongjuensis KCTC $19054^{\mathrm{T}}$, was absent in strain Gsoil $346^{\mathrm{T}}$ (see Supplementary Table S1, available in IJSEM Online). Phosphatidylinositol and phosphatidylglycerol were detected as the major polar lipids (see Supplementary Fig. S1).

On the basis of the 16S rRNA gene sequence analysis of strain Gsoil $346^{\mathrm{T}}$ and the type strains of species of the genus Nocardioides and unique phenotypic characteristics (Table 1 and Supplementary Table S1), we have demonstrated that strain Gsoil $346^{\mathrm{T}}$ is not affiliated with any existing species of the genus Nocardioides. Therefore, strain Gsoil $346^{\mathrm{T}}$ should be placed in the genus Nocardioides as a representative of a novel species, for which we propose the name Nocardioides panacisoli sp. nov.

\section{Description of Nocardioides panacisoli sp. nov.}

Nocardioides panacisoli (pa.na.ci.so'li. N.L. n. Panax -acis scientific name of ginseng; L. n. solum -i soil; N.L. gen. n. panacisoli of soil of a ginseng field, the source of isolation of the organism).

Cells are Gram-positive, strictly aerobic, non-spore-forming, non-motile and short rod-shaped, $0.2-0.4 \mu \mathrm{m}$ in diameter and $0.8-1.2 \mu \mathrm{m}$ in length after 3 days of growth at $30{ }^{\circ} \mathrm{C}$ on R2A agar. Colonies on R2A agar are smooth, circular, light yellowish white and convex after 4 days. Grow at $10-42{ }^{\circ} \mathrm{C}$ (optimum $18-37{ }^{\circ} \mathrm{C}$ ), but not at $4{ }^{\circ} \mathrm{C}$ or $45{ }^{\circ} \mathrm{C}$. Optimum $\mathrm{pH}$ for growth is $\mathrm{pH}$ 5.5-8.5. Growth 
occurs in the absence of $\mathrm{NaCl}$ and in the presence of $2.0 \%$ $(\mathrm{w} / \mathrm{v}) \mathrm{NaCl}$, but not $3.0 \%(\mathrm{w} / \mathrm{v}) \mathrm{NaCl}$. Catalase- and oxidase production are positive. Nitrate is reduced. Production of urease, arginine dihydrolase, lysine decarboxylase, ornithine decarboxylase, tryptophan deaminase and $\beta$-galactosidase and Voges-Proskauer test are negative. Produces $\mathrm{H}_{2} \mathrm{~S}$ from sodium thiosulfate. Does not produce acid or gas from glucose, does not produce indole from tryptophan and does not degrade xylan, starch, chitin or cellulose. The following compounds are utilized as sole carbon sources: acetate, adipate, citrate, 3-hydroxybutyrate, gluconate, D-glucose, L-malate, maltose, L-proline, propionate, sucrose and valerate. The following compounds are not utilized as sole carbon sources: $\mathrm{N}$-acetylglucosamine, L-alanine, L-arabinose, caprate, L-fucose, glycogen, Lhistidine, 3-hydroxybenzoic acid, inositol, itaconate, 5ketogluconate, L-lactic acid, malonate, D-mannitol, Dmannose, melibiose, phenylacetate, L-rhamnose, D-ribose, salicin, L-serine, D-sorbitol and suberate. According to the results from the API ZYM tests, 2-naphthyl phosphate ( $\mathrm{pH}$ 8.5), 2-naphthyl phosphate ( $\mathrm{pH} 5.4$ ), N-benzoyl-DLarginine 2-naphthylamide, $\mathrm{N}$-glutaryl-phenylalanine 2naphthylamide, naphthol-AS-BI-phosphate and 2-naphthyl $\alpha$-D-glucopyranoside are hydrolysed, but 2-naphthyl butyrate, 2-naphthyl caprylate, 2-naphthyl myristate, L-leucyl 2naphthylamide, L-valyl 2-naphthylamide, L-cystyl 2naphthylamide, 6-bromo-2-naphthyl $\alpha$-D-galactopyranoside, 2 -naphthyl $\beta$-D-galactopyranoside, naphthol-AS-BI- $\beta$ D-glucuronide, 6-bromo-2-naphthyl $\beta$-D-glucopyranoside, 1-naphthyl $\quad N$-acetyl- $\beta$-D-glucosaminide, $\quad 6$-bromo-2naphthyl $\alpha$-D-mannopyranoside and 2-naphthyl $\alpha$-L-fucopyranoside are not hydrolysed. MK- $8\left(\mathrm{H}_{4}\right)$ is the predominant menaquinone and iso- $\mathrm{C}_{16: 0}, \mathrm{C}_{18: 1} \omega 9 c$ and $\mathrm{C}_{17: 1} \omega 8 c$ are the major components of cellular fatty acids. The cellwall peptidoglycan contains LL-2,6-diaminopimelic acid. The major polar lipids are phosphatidylinositol and phosphatidylglycerol. The genomic DNA G $+\mathrm{C}$ content of the type strain is $73.0 \mathrm{~mol} \%$ (HPLC).

The type strain, Gsoil $346^{\mathrm{T}}\left(=\right.$ KCTC $19470^{\mathrm{T}}=\mathrm{DSM}$ $21348^{\mathrm{T}}$ ), was isolated from the soil of a ginseng field in Pocheon province, South Korea.

\section{Acknowledgements}

This work was supported by a grant from the KRIBB Research Initiative Program.

\section{References}

An, D.-S., Im, W.-T., Lee, S.-T. \& Yoon, M.-H. (2007). Nocardioides panacihumi sp. nov., isolated from soil of ginseng field. Int J Syst Evol Microbiol 57, 2143-2146.

Atlas, R. M. (1993). Handbook of Microbiological Media. Edited by L. C. Parks. Boca Raton, FL: CRC Press.

Bates, R. G. \& Bower, V. E. (1956). Alkaline solutions for pH control. Anal Chem 28, 1322-1324.
Buck, J. D. (1982). Nonstaining (KOH) method for determination of Gram reactions of marine bacteria. Appl Environ Microbiol 44, 992-993.

Chou, J.-H., Cho, N.-T., Arun, A. B., Young, C.-C. \& Chen, W.-M. (2008). Nocardioides fonticola sp. nov., a novel actinomycete isolated from spring water. Int J Syst Evol Microbiol 58, 1864-1868.

Chun, J., Lee, J.-H., Jung, Y., Kim, M., Kim, S., Kim, B. K. \& Lim, Y.-W. (2007). EzTaxon: a web-based tool for the identification of prokaryotes based on $16 \mathrm{~S}$ ribosomal RNA gene sequences. Int J Syst Evol Microbiol 57, 2259-2261.

Dastager, S. G., Lee, J.-C., Ju, Y.-J., Park, D.-J. \& Kim, C.-J. (2008). Nocardioides koreensis sp. nov., Nocardioides bigeumensis sp. nov. and Nocardioides agariphilus sp. nov., isolated from soil from Bigeum Island, Korea. Int J Syst Evol Microbiol 58, 2292-2296.

Felsenstein, J. (1985). Confidence limits on phylogenies: an approach using the bootstrap. Evolution 39, 783-791.

Felsenstein, J. (2004). PHYLIP (phylogeny inference package), version 3.6. Distributed by the author. Department of Genome Sciences, University of Washington, Seattle, USA.

Fitch, W. M. (1971). Toward defining the course of evolution: minimum change for a specific tree topology. Syst Zool 20, 406-416.

Gomori, G. (1955). Preparation of buffers for use in enzyme studies. Methods Enzymol 1, 138-146.

Hall, T. A. (1999). BioEdit: a user-friendly biological sequence alignment editor and analysis program for Windows 95/98/NT. Nucleic Acids Symp Ser 41, 95-98.

Hiraishi, A., Ueda, Y., Ishihara, J. \& Mori, T. (1996). Comparative lipoquinone analysis of influent sewage and activated sludge by highperformance liquid chromatography and photodiode array detection. J Gen Appl Microbiol 42, 457-469.

Im, W.-T., Jung, H.-M., Cui, Y.-S., Liu, Q.-M., Zhang, S.-L. \& Lee, S.-T. (2005). Cultivation of the three hundreds of bacterial species from soil of a ginseng field and mining the novel lineage bacteria. In Proceedings of the International Meeting of the Federation of Korean Microbiological Societies, abstract A035, p. 169. Seoul: Federation of Korean Microbiological Societies.

Kim, M. K., Im, W.-T., Ohta, H., Lee, M. \& Lee, S.-T. (2005). Sphingopyxis granuli sp. nov., a $\beta$-glucosidase producing bacterium in the family Sphingomonadaceae in $\alpha-4$ subclass of the Proteobacteria. J Microbiol 43, 152-157.

Kim, H. M., Choi, D. H., Hwang, C. Y. \& Cho, B. C. (2008). Nocardioides salarius sp. nov., isolated from seawater enriched with zooplankton. Int J Syst Evol Microbiol 58, 2056-2064.

Kimura, M. (1983). The Neutral Theory of Molecular Evolution. Cambridge: Cambridge University Press.

Komagata, K. \& Suzuki, K. (1987). Lipid and cell-wall analysis in bacterial systematics. Methods Microbiol 19, 161-207.

Kubota, M., Kawahara, K., Sekiya, K., Uchida, T., Hattori, Y., Futamata, H. \& Hiraishi, A. (2005). Nocardioides aromaticivorans sp. nov., a dibenzofuran-degrading bacterium isolated from dioxinpolluted environments. Syst Appl Microbiol 28, 165-174.

Kumar, S., Dudley, J., Nei, M. \& Tamura, K. (2007). MEGA4: molecular evolutionary genetics analysis (MEGA) software version 4.0. Mol Biol Evol 24, 1596-1599.

Lee, S. D., Lee, D. W. \& Kim, J.-S. (2008). Nocardioides hwasunensis sp. nov. Int J Syst Evol Microbiol 58, 278-281.

Mesbah, M., Premachandran, U. \& Whitman, W. B. (1989). Precise measurement of the $\mathrm{G}+\mathrm{C}$ content of deoxyribonucleic acid by highperformance liquid chromatography. Int J Syst Bacteriol 39, 159-167.

Minnikin, D. E., Patel, P. V., Alshamaony, L. \& Goodfellow, M. (1977). Polar lipid composition in the classification of Nocardia and related bacteria. Int J Syst Bacteriol 27, 104-117. 
Moore, D. D. \& Dowhan, D. (1995). Preparation and analysis of DNA. In Current Protocols in Molecular Biology, pp. 2-11. Edited by F. M. Ausubel, R. Brent, R. E. Kingston, D. D. Moore, J. G. Seidman, J. A. Smith \& K. Struhl. New York: Wiley.

Prauser, H. (1976). Nocardioides, a new genus of the order Actinomycetales. Int J Syst Bacteriol 26, 58-65.

Reasoner, D. J. \& Geldreich, E. E. (1985). A new medium for the enumeration and subculture of bacteria from potable water. Appl Environ Microbiol 49, 1-7.

Saitou, N. \& Nei, M. (1987). The neighbor-joining method: a new method for reconstructing phylogenetic trees. Mol Biol Evol 4, 406425.

Sasser, M. (1990). Identification of bacteria by gas chromatography of cellular fatty acids, MIDI Technical Note 101. Newark, DE: MIDI Inc.

Schippers, A., Schumann, P. \& Spröer, C. (2005). Nocardioides oleivorans sp. nov., a novel crude-oil-degrading bacterium. Int J Syst Evol Microbiol 55, 1501-1504.

Suzuki, K.-I. \& Komagata, K. (1983). Pimelobacter gen. nov., a new genus of coryneform bacteria with LL-diaminopimelic acid in the cell wall. J Gen Appl Microbiol 29, 59-72.

Ten, L. N., Im, W.-T., Kim, M.-K., Kang, M. S. \& Lee, S.-T. (2004). Development of a plate technique for screening of polysaccharidedegrading microorganisms by using a mixture of insoluble chromogenic substrates. J Microbiol Methods 56, 375-382.

Thompson, J. D., Gibson, T. J., Plewniak, F., Jeanmougin, F. \& Higgins, D. G. (1997). The CLUSTAL_X windows interface: flexible strategies for multiple sequence alignment aided by quality analysis tools. Nucleic Acids Res 25, 4876-4882.

Tschech, A. \& Pfennig, N. (1984). Growth yield increase linked to caffeate reduction in Acetobacterium woodii. Arch Microbiol 137, 163167.

Tóth, E. M., Kéki, Z., Homonnay, Z. G., Borsodi, A. K., Marialigeti, K. \& Schumann, P. (2008). Nocardioides daphniae sp. nov., isolated from Daphnia cucullata (Crustacea: Cladocera). Int J Syst Evol Microbiol 58, 78-83.

Widdel, F. \& Bak, F. (1992). Gram-negative mesophilic sulfate reducing bacteria. In The Prokaryotes, 2nd edn, vol. 4, pp. 3352-3378. Edited by A. Balows, H. G. Trüper, M. Dworkin, W. Harder \& K. H. Schleifer. New York: Springer-Verlag.

Widdel, F., Kohring, G.-W. \& Mayer, F. (1983). Studies in dissimilatory sulfate-reducing bacteria that decompose fatty acids. III. Characterization of the filamentous gliding Desulfonema limicola gen. nov., sp. nov. and Desulfonema magnum sp. nov. Arch Microbiol 134, 286-294.

Yi, H. \& Chun, J. (2004). Nocardioides aestuarii sp. nov., isolated from tidal flat sediment. Int J Syst Evol Microbiol 54, 2151-2154.

Yoon, J.-H., Cho, Y.-G., Lee, S. T., Suzuki, K., Nakase, T. \& Park, Y.-H. (1999). Nocardioides nitrophenolicus sp. nov., a p-nitrophenoldegrading bacterium. Int J Syst Bacteriol 49, 675-680.

Yoon, J.-H., Lee, J.-K., Jung, S.-Y., Kim, J.-A., Kim, H.-K. \& Oh, T.-K. (2006). Nocardioides kongjuensis sp. nov., an $N$-acylhomoserine lactone-degrading bacterium. Int J Syst Evol Microbiol 56, 1783-1787. 